\title{
A new Agdistis from St. Helena Island (Lepidoptera, Pterophoridae)
}

With 7 figures

Ernst Arenberger ${ }^{1}$, Annalea M. Beard ${ }^{2}$ and Timm KarisCH $^{3}$

${ }^{1}$ Naturhistorisches Museum Wien, Burgring 7, 1010 Wien, Österreich. - ernst.arenberger@chello.at

${ }^{2}$ Heathfield, Dewlands Common, Verwood, Dorset, England BH31 6JL. - annaleamichellebeard@yahoo.co.uk

${ }^{3}$ Museum für Naturkunde und Vorgeschichte Dessau, Askanische Straße 32, 06842 Dessau, Deutschland. - Timm.Karisch@ naturkunde.dessau.de

Published on 2016-12-20

\section{Summary}

Agdistis cambriana spec. nov. is described as new species. Imago and genitalia are illustrated.

\section{Key words}

St. Helena, fauna, Pterophoridae, Agdistis cambriana spec. nov.

\section{Zusammenfassung}

Agdistis cambriana spec. nov. wird als neue Art beschrieben, Imago und Genitale werden abgebildet.

\section{Introduction}

St. Helena is a small 122 square kilometres island in the South Atlantic. First studies of the Lepidoptera fauna were conducted in the second half of the 19th Century. At the end of the 20th Century three species of Pterophoridae had been recorded: Stenodacma wahlbergi (Zeller, 1852), Hellinsia subnotata (WALKer, 1875) and Agdistis sanctae-helenae Wollaston, 1879 (Bigot, 1975; Karisch, 2003; Ashmole \& Ashmole, 2000). In 2011 a second Agdistis species was discovered by the second author (AMB) in southwest St. Helena and described under the name Agdistis marionae ArenBerger, Beard, Hasenfuss \& Karisch, 2012.

\section{Material and Methods}

Among the specimens of Agdistis marionae sent to the third author (TK) in 2011, there was a specimen from the north of the island (Cambrian House east of Jamestown). Later, David Pryce (St. Helena National Trust) has collected further material of Agdistis from the northern part of the island using a malaise-trap at Rupert's Valley. The specimens were placed in a tube with ethanol and sent to the third author (TK), who removed seven specimens, dried and spread them. Three genitalia dissections were made following Robinson (1976). 


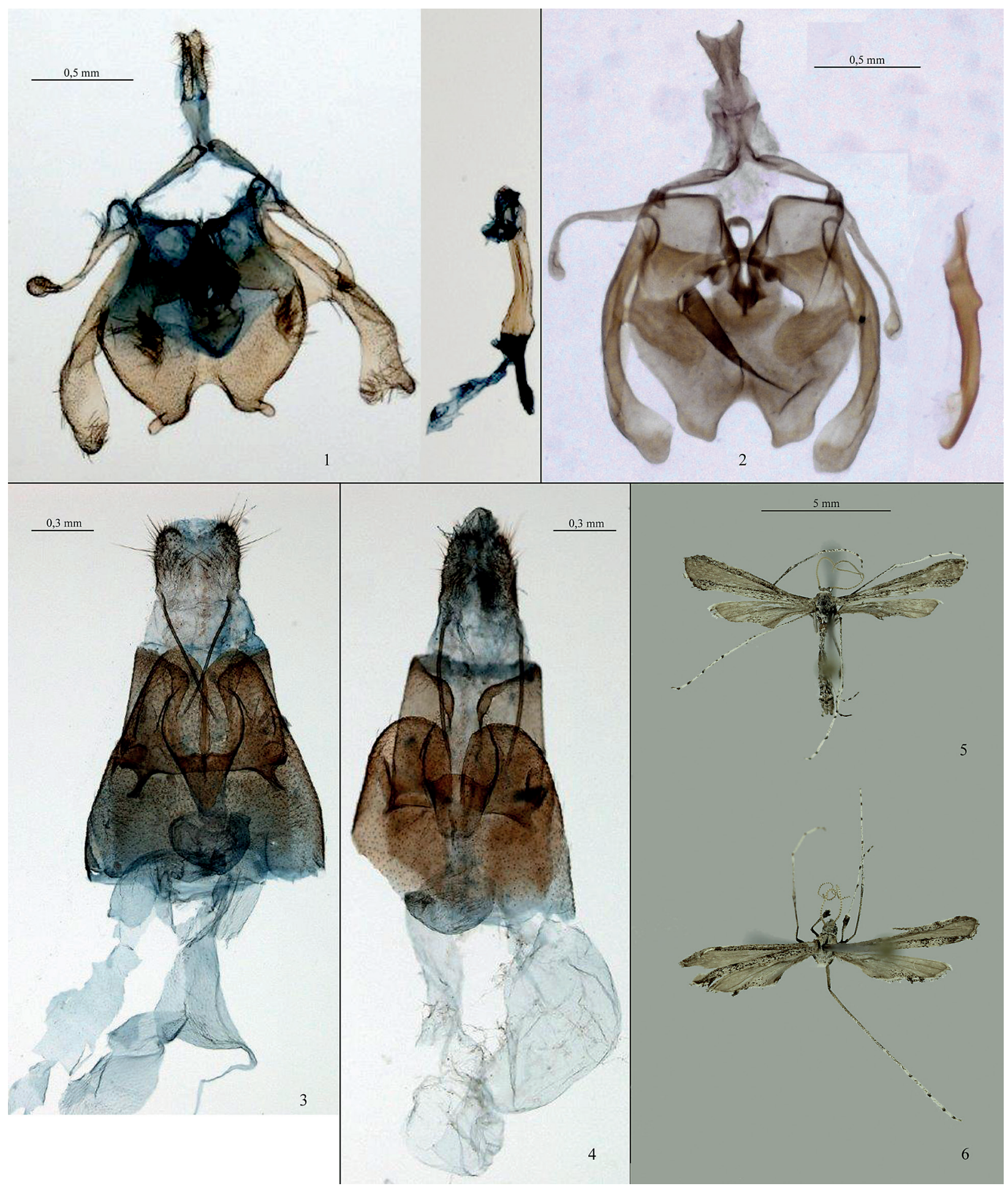

Fig. 1: Agdistis marionae Arenberger, BeArd, Hasenfuss \& Karisch, 2012; male genitalia.

Fig. 2: Agdistis cambriana spec. nov.: male genitalia.

Fig. 3: Agdistis marionae Arenberger, BeArd, Hasenfuss \& Karisch, 2012: female genitalia.

Fig. 4: Agdistis cambriana spec. nov.: female genitalia.

Fig. 5: Agdistis cambriana spec. nov.: imago, holotype, male.

Fig. 6: Agdistis cambriana spec. nov.: imago, paratype, male.

Photographs 1, 3, 4 by E. Arenberger, 2, 5, 6 by T. Karisch. 


\section{Results}

The first author (EA) detected some differences in genitalia between the specimen from Jamestown and the series from the South West of the island. That's why the specimen was taken out of the type series of $A$. marionae and remained unidentified until the vast collection of D. PRYCE was received. This collection contains males only, whereas the specimen from Jamestown is a female. Because the study sites are very close (about $1,5 \mathrm{~km}$ distance) in neighbouring valleys we suppose that all specimens belong to only one species.

Comparison of the structure of the male and female genitalia shows clearly that the Agdistis from the north of St. Helena belong to a second, hitherto unknown species. It is described below.

\section{Abbreviations}

coll. Collection

Fig. Figure

GU genitalia preparation

BMNH The Natural History Museum London

MNVD Museum für Naturkunde und Vorgeschichte Dessau

NHMW Naturhistorisches Museum Wien

\section{Agdistis cambriana spec. nov.}

Holotype, o": "St. Helena, Rupert's Valley, WGS 84 $15^{\circ} 55.460$ 'S, $5^{\circ} 42.650^{\prime} \mathrm{W}, 36$ MASL, 02-23/V/2014, Malaise trap, coll. David Pryce". Coll. MNVD.

Paratypes: $6 o^{\star} o^{\star}$ (2 $o^{\star} o^{\star}$ GU 3320, 3321 KARISCH) with the same data as holotype, coll. MNVD, NHMW, BMNH; 1 ㅇ (GU 6450, Arenberger) St. Helena, Upper Jamestown, Cambrian House, 05.II.2011, leg. A. M. BEARD, coll. NHMW.

Etymology: Named from the locality at Cambrian House, Jamestown, St. Helena.

Diagnosis (Figs 5, 6): Wingspan: 11.5-13 mm. Head, thorax and abdomen grey-brown; palpi at base dark brown, tips grey; antenna brown, whitish spotted. Forewing grey-brown, covered with numerous brown scales. Costal margin with two dots, lower fold margin with two large, brown patches which extend to the fringes. Hindwing monochrome grey-brown, anal margin with scattered dark brown scales. Hind legs grey, tarsi white, terminally brown.

Genitalia ${ }^{\star}$ (Fig. 2): uncus similar to that of $A$. marionae, but caudal margin concave incised, lateral tips divergent. Valvae symmetrical, basal parts dumpy, in distal half slender, strip-shaped; outer parts of valva bent, bar-shaped, broadened at the end, but not crenate as in

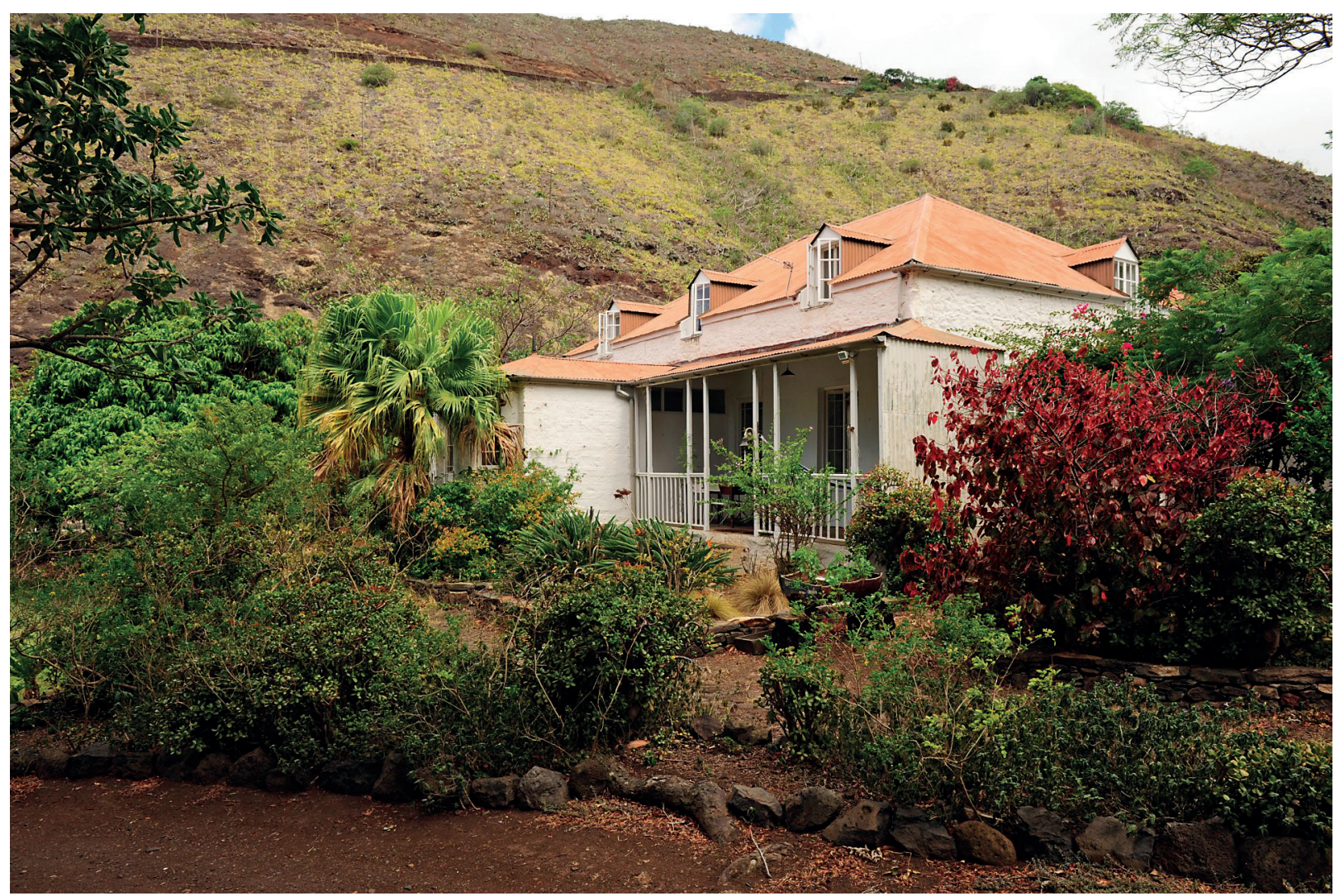

Fig. 7: Cambrian House and its surroundings, habitat of Agdistis cambriana spec. nov.

Photograph by E. THORPE. 
A. marionae (Fig. 1); costal arms slender, strongly curved distally. Aedeagus rather slender, slightly arcuate. $8^{\text {th }}$ sternite plate-shaped, caudal margin with two broad lobes.

Genitalia 9 (Fig. 4): antrum similar to that of A. marionae (Fig. 3), but considerably shorter and lateral setae of antrum are less bent.

Biological notes: The caterpillar of A.cambriana spec. nov. is unknown. The imago has been caught in February and May. The habitat is an area with sparse scrub vegetation and some gardens near the north coast of the island (Fig. 7).

Differential diagnosis: Imago of A.cambriana spec. nov. with two costal dots, lacking in A. marionae. In A. marionae only basal part of forewing darkened, in A. cambriana spec. nov. the whole forewing uniform grey-brown, scattered with brown scales. In $\sigma^{\lambda}$-genitalia, distal end of uncus in A. cambriana spec. nov. broad with two divergent tips, in A.marionae tips strongly approximated. Tip of right valva rounded, in A. marionae crenate. Caudal margin of $8^{\text {th }}$ sternite bilobed in both species, but in A. marionae tips are short, outwardly bent, and in A. cambriana spec. nov. they form broad plates. Antrum in A. marionae considerably longer and more slender than in A. cambriana spec. nov.

Distribution: Likely endemic to St. Helena.

Remarks: In Arenberger et al. (2012), the illustration of the female genitalia, given as A.marionae (Fig. 3) is incorrect: it is in fact A. cambriana spec. nov. (slide no. 6450, Arenberger) (Fig. 4).

\section{Acknowledgement}

We thank Mr. B. GoATER, Chandler's Ford, who checked the English text.

\section{References}

Arenberger, E.; Beard, A. M.; Hasenfuss, I. \& KARISCH, T. 2012: Agdistis marionae sp.n., a new Pterophoridae from St. Helena (Lepidoptera). Beiträge zur Entomologie 62: 447-457.

Ashmole, P. \& Ashmole, M. 2000: St. Helena and Ascension Island: A Natural History. - Shropshire, Anthony Nelson: $475 \mathrm{~S}$.

Bigot, L. 1975: Deux Pterophoridae de l'ile Sainte Helene. - Lambillionea LXXV (7-8): 62-64.

KARISCH, T. 2003: Zur Schmetterlingsfauna von St. Helena. 2. Teil: Kleinschmetterlinge (1) (Insecta: Lepidoptera: Tortricidae, Glyphipterigidae, Cosmopterigidae, Plutellidae, Pterophoridae). - Linzer biologische Beiträge 35 (2): 1081-1085.

Robinson, G. S. 1976: The preparation of slides of Lepidoptera genitalia with special reference to the Microlepidoptera. - Entomologist's Gazette 27: 127-132. 